Institute of $\mathbf{F}_{\text {ood and }} \mathbf{A}$ gricultural $\mathbf{S}_{\text {ciences }}$

\title{
Florida Solid and Hazardous Waste Regulation Handbook: Comprehensive Environmental Response, Compensation, and Liability Act (CERCLA) ${ }^{1}$
}

Michael T. Olexa, Aaron Leviten, and Kelly Samek ${ }^{2}$

\section{What Is the Comprehensive Environmental Response, Compensation, and Liability Act (CERCLA)?}

The Comprehensive Environmental Response, Compensation, and Liability Act (CERCLA) was enacted in 1980, and later amended by the Superfund Amendments and Reauthorization Act (SARA) in 1986. CERCLA empowers EPA to investigate and cleanup abandoned sites contaminated by hazardous substances and provides a trust fund for that purpose.

CERCLA extends liability for site pollution to several classes of potential defendants at once. It is a powerful measure for forcing responsible parties to contribute to the costs of cleanup.

\section{What Substances Are Regulated?}

CERCLA cleanup provisions cover all substances designated as hazardous under the following acts of Congress:
- Clean Water Act (CWA).

- Comprehensive Environmental Response, Compensation, and Liability Act (CERCLA).

- Resource Conservation and Recovery Act (RCRA).

- Clean Air Act (CAA).

- Toxic Substances Control Act (TSCA).

\section{What Substances Are Excluded?}

Substances excluded from CERCLA coverage include:

- petroleum, including crude oil or any fraction thereof, which is not otherwise designated as a hazardous substance under another statute.

- natural gas or natural gas liquids.

- liquified natural gas.

1. This is EDIS document FE445, a publication of the Department of Food and Resource Economics, Florida Cooperative Extension Service, UF/IFAS, University of Florida, Gainesville, FL. Published December 2003. Please visit the EDIS website at http://edis.ifas.ufl.edu.

2. Michael T. Olexa, Professor in the Department of Food and Resource Economics and Director of the Agricultural Law Center, Florida Cooperative Extension Service, UF/IFAS, University of Florida, Gainesville, FL, and Member of the Florida Bar and Chair of the Agricultural Law Committee of the Florida Bar; Aaron Leviten, Attorney in Orlando and guest lecturer on pesticide litigation at the University of Florida; and Kelly Samek, 2003 graduate of the Levin College of Law at the University of Florida.

The Institute of Food and Agricultural Sciences is an equal opportunity/affirmative action employer authorized to provide research, educationa information and other services only to individuals and institutions that function without regard to race, color, sex, age, handicap, or national origin. For information on obtaining other extension publications, contact your county Cooperative Extension Service office. Florida Cooperative Extension Service/Institute of Food and Agricultural Sciences/University of Florida/Christine Taylor Waddill, Dean. 
- synthetic gas usable for fuel.

Although petroleum and petroleum products are specifically excluded from regulation under CERCLA, Congress has enacted provisions under RCRA that impose liability on owners of petroleum storage tanks.

\section{Who Is Regulated by CERCLA?}

CERCLA is aimed at 4 types of potentially responsible parties (PRPs):

1. landowners of contaminated sites.

2. operators of contaminated sites.

3. transporters of hazardous substances to and from contaminated sites.

4. generators who produced or possessed the hazardous waste disposed of at the site.

Courts have broadly interpreted CERCLA to reach everyone who may have been in any way responsible for a site's contamination. A partial list of people who have faced liability under CERCLA includes:

- current and past owners who purchased land without knowledge of the hazardous pollutants there.

- current land owners who merely act as landlords.

- lessees and sub-lessees, if they had control of the site when it was contaminated.

- past landowners who owned the site when it was contaminated.

- government entities that may have been involved in regulating the site.

- any commercial entity including corporations, associations, partnerships, and sole proprietorships.

- corporate officers and management employees of companies who had control of the companies when the site was contaminated.
- anyone who arranged for the disposal of the hazardous waste.

- foreclosing banks, lien holders, creditors and mortgage companies.

- companies that innocently purchased the facilities where hazardous waste is buried.

- moving companies.

It is important to note that owners may be held liable even if they purchased land without knowledge of hazardous waste buried there. This has been a source of great concern to land buyers, foreclosing banks, and others about to acquire land.

\section{How Is Liability Determined under CERCLA?}

CERCLA imposes strict liability and therefore does not require a specific finding of negligence before penalties may be imposed. CERCLA also provides for joint and several liability, which allows EPA to force a party who may be responsible for only part of the damage to pay the entire cost of cleanup. Joint and several liability simply means that EPA may seek to recover some or all of the cleanup costs from any party or combination of parties it finds responsible for damage.

\section{What Are the Defenses to Liability under CERCLA?}

Legal defenses to CERCLA liability are limited to:

- acts of God.

- acts of war.

- actions of a third party.

- the innocent landowner defense.

- the security interest exemption.

There is a defense that is not specifically listed, but may be used. If a site were contaminated by pesticide application, you would not be liable under CERCLA if you followed all label instructions (under FIFRA). 
The third-party defense may only be used when the third party is entirely responsible for the contamination and when there is no contract between the defendant and the third party. For example this defense may not be used if there is a sales contract between the current owner (the defendant) and the prior owner (the third party whose actions caused the contamination). In that situation the innocent landowner defense would apply.

The security interest exemption protects lenders (such as banks) from liability when the lender acquires ownership through a default or foreclosure on a mortgage and does not participate in the management of the facility.

The innocent landowner defense applies when a new landowner did not know and had no reason to know that a previous landowner had contaminated the property. It can be very difficult for a new landowner to prove this defense. The best way is with an environmental audit. An audit demonstrates that the new landowner used due diligence and took all appropriate actions to find out whether there was any likelihood of contamination. For this reason, environmental audits have become very popular with purchasers of land as a form of protection from liability.

\section{What Is an Environmental Audit?}

An audit is:

- an evaluation of the condition of land.

- an appraisal of whether the lender or buyer is likely to become subject to some type of enforcement action.

Under CERCLA, all buyers, even buyers without knowledge of buried contaminants, may be held liable for cleanup costs. Thus buyers and lenders alike should conduct an audit before purchasing property that may be contaminated. This audit can help you avoid being made responsible for the prior owners' cleanup costs.

\section{What Does CERCLA Require?}

CERCLA requires that the location of any site containing hazardous materials be reported to EPA. Additionally, prompt notification is also required after any spill or release of contaminated materials into the environment. Failure to report in either case may result in fines and or imprisonment.

\section{Who Is Responsible for Enforcing CERCLA?}

EPA is the chief enforcer of CERCLA, although the President is authorized to enter into agreements with states that wish to enforce the provisions of the statute. EPA must consult with state and local officials before deciding upon remedies for contamination at federal facilities.

\section{How Is CERCLA Enforced?}

EPA may begin investigations whenever there is reason to believe that a release has occurred or may occur. EPA, or a state or local authority acting under agreement with EPA, may require the person or business under investigation to provide them with:

- information about the nature and handling of all hazardous materials on the site.

- information related to the subject's ability to pay for the cleanup.

EPA may enter, at reasonable times, any site dealing with hazardous materials and take samples from the site. If EPA requests are denied during the investigation phase, the agency may issue compliance orders to compel cooperation. EPA can enforce these orders with civil fines of up to $\$ 25,000$ per day.

\section{What Are the Procedures for a Cleanup?}

If the investigation confirms that a hazardous substance (or a pollutant or contaminant with the potential to pose an imminent threat to public health) has been released or may be released, EPA may exercise any combination of several response options: 
- removal action.

- remedial action.

- enforcement.

EPA prefers permanent, cost-effective measures whenever possible. Also, the cleanup must be in accordance with other appropriate federal or state environmental statutes.

EPA, or the state, may undertake the cleanup. The responsible parties may be permitted to begin a private cleanup if they can demonstrate to EPA that it will be as effective as the proposed EPA measures. This alternative may be much less costly for parties who would otherwise be forced to pay for a cleanup conducted by EPA or the state.

\section{Acknowledgments}

The authors are indebted to the personnel of both state and federal agencies who gave their time and advice in the preparation of this handbook. The authors are also indebted to the following University of Florida personnel for a review and critique of the first draft of this publication: Dr. Thomas Dean, Pesticide Education Specialist, and Dr. Norman Nesheim, Pesticide Information Coordinator. Special recognition is also due to Mr. Richard Budell of the Office of Agricultural Water Policy of the Florida Department of Agriculture and Consumer Services for providing funds for the development of this handbook.

This handbook is designed to provide an accurate, current, and authoritative summary of the principal Florida laws that directly or indirectly relate to agriculture. It should provide a basic overview of the many rights and responsibilities farmers and farmland owners have under Florida laws. The reader is provided information about these rights and responsibilities and the appropriate contacts for more detailed information. However, the reader should be aware that because the laws, administrative rulings, and court decisions on which this publication is based are subject to constant revision, portions of this publication could become outdated at any time. Many details of cited laws are also left out due to space limitations.
This handbook is distributed with the understanding that the authors are not engaged in rendering legal or other professional advice and the information contained herein should not be regarded or relied upon as a substitute for professional advice. It is not all-inclusive in providing information to achieve compliance with laws and regulations governing the practice of agriculture. For these reasons, the use of these materials by any person constitutes an agreement to hold harmless the authors, UF/IFAS, the Agricultural Law Center, and the University of Florida for any liability claims, damages, or expenses that may be incurred by any person as a result of reference to or reliance upon the information contained in this publication. 